\title{
KAJIAN IN SILICO SENYAWA TURUNAN KLOROKALKON SEBAGAI ANTIKANKER
}

\author{
Didi Fadilla $^{1, \dagger}$, Hanggara Arifian ${ }^{1}$, Agung Rahmadani ${ }^{1}$, Rolan Rusli ${ }^{1,2, \sharp}$ \\ ${ }^{1}$ Laboratorium Penelitian dan Pengembangan Kefarmasian "Farmaka Tropis", \\ Fakultas Farmasi, Universitas Mulawarman, Samarinda, Indonesia \\ †Email: Didifadilla@gmail.com \\ ${ }^{2}$ Kelompok Bidang Ilmu Kimia Farmasi, Fakultas Farmasi, \\ Universitas Mulawarman, Samarinda, Indonesia \\ *Email: rolan@farmasi.unmul.ac.id
}

\begin{abstract}
ABSTRAK
Perancangan obat baru dapat dilakukan dengan metode in silico melalui modifikasi struktur dengan mengubah gugus tersubstitusi yang dapat menyebabkan perubahan aktivitas suatu senyawa. Kalkon sebagai metabolit sekunder memiliki berbagai aktivitas biologis seperti antioksida, antikanker, antibakteri, dan antivirus. Senyawa kalkon dioptimasi dan dilakukan docking menggunakan program MOE Chemical Computing Group terhadap enzim target SIRT1 dengan kode pdb.4I5I. Aktivitas sitotoksik senyawa kalkon hasil modifikasi pada protein target ditunjukkan melalui interaksi arene-cation dan ikatan hidrogen.
\end{abstract}

Kata Kunci: In silico, Klorokalkon, interaksi molekul, antikanker, aktivitas sitotoksik

DOI: https://doi.org/10.25026/mpc.v7i1.293

\section{PENDAHULUAN}

Perancangan obat adalah suatu usaha untuk mengembangkan obat yang telah ada. Rancangan obat digambarkan sebagai proses elaborasi sistematis untuk mengembangkan lebih lanjut obat yang sudah ada dengan tujuan mendapatkan obat baru dengan aktivitas yang lebih baik dan mengurangi atau menghilangkan efek samping yang ada melalui manipulasi molekul [1].

Pengembangan bahan obat diawali dengan sintesis atau isolasi dari berbagai sumber yaitu dari tanaman, jaringan hewan, kultur mikroba, dan dengan teknik bioteknologi. Setelah diperoleh bahan calon obat, maka selanjutnya calon obat tersebut akan melalui serangkaian uji yang memakan waktu yang panjang dan biaya yang tidak sedikit sebelum diresmikan sebagai obat oleh Badan pemberi izin. Biaya yang diperlukan dari mulai isolasi atau sintesis senyawa kimia sampai diperoleh obat baru lebih kurang US\$ 500 juta per obat. Uji yang harus ditempuh oleh calon obat adalah uji praklinik dan uji klinik [2].

Mengatasi hambatan tersebut, munculah unsur baru diantara eksperimen dan teori yaitu eksperimen komputer (Computer Experiment). Perkembangan eksperimen komputer mengubah secara substansial hubungan tradisional antara teori dan eksperimen. Penelitian kimia 
dengan alat komputer dimulai dengan kajian hubungan struktur kimia dengan aktivitas fisiologi dari senyawa [3]. Dengan mempelajari hubungan struktur obat dan aktivitasnya maka pencarian zat baru lebih terarah dan memunculkan ilmu baru yaitu kimia medisinal dan farmakologi molekular.

Kimia medisinal adalah multidisiplin ilmu yang terlibat dalam desain, sintesis obat potensial diikuti oleh studi pemeriksaan interaksi mereka dengan target biologis untuk memahami efek obat, metabolisme dan efek samping. pengembangan obat dengan memanfaaatkan kimia medisinal dapat dilakukan dengan berbagai macam pendekatan seperti pendekatan secara biokimia maupun secara komputasi.

Kimia komputasi dapat digunakan untuk menjelaskan beragam sistem kimia dengan kompleksitas yang sangat luas, sehingga membantu dalam bidang desain dan optimasi proses yang baru atau proses yang sedang berjalan maupun produk. Kimia komputasi dapat mereduksi biaya pengembangan, meningkatkan efisiensi energi, dan daya guna lingkungan, dan menaikkan produktivitas dan keuntungan [4]. Penelitian kimia komputasi dalam bidang terapan dilakukan dengan mempelajari korelasi antara struktur-aktivitas atau struktur-sifat terhadap data percobaan yang telah diperoleh dari penelitian.

Banyak aplikasi kimia komputasi dapat dimanfaatkan untuk memprediksikan sifat dan kelakuan sistem kimia dalam proses kimia. Dengan mengetahui kelakuan sistem, kimia komputasi mempunyai potensi untuk meningkatkan efisiensi dari sistem operasi yang sedang digunakan atau bahkan mendesain sistem baru yang lebih handal sehingga akan dicapai optimasi proses dan peningkatan efisiensi energi.

Usaha pengembangan senyawa aktif tanaman telah dilakukan untuk dijadikan sebagai bahan sediaan obat. Mengingat bahwa, terdapat banyak sekali tanaman yang memiliki sisi aktif dengan dilakukannya pengujian sistem coba-coba (trial and error) mengakibatkan tingginya tingkat penggunaan bahan uji tanpa adanya suatu prediksi efektifitas senyawa aktif. Hal inilah yang dapat mengakibatkan kurangnya efisiensi dalam penelitian dan memerlukan waktu yang cukup lama.

Berbagai senyawa bahan alam yang aktif bagi tanaman banyak ditemukan dengan menggunakan proses isolasi. Senyawa tersebut diharapkan mampu dijadikan sebagai sisi aktif obat yang berikatan dengan reseptornya, salah satunya adalah kalkon. Sejauh ini pengembangan senyawa kalkon dilakukan dengan modifikasi substituen pada kerangka dasarnya melalui sintesis kimia. Akan tetapi, kalkon sangat susah diisolasi dari tanaman karena adanya enzim kalkon sintetase (CSH) yang dengan mudah mengubah kalkon menjadi flavanon.

Kalkon merupakan metabolit sekunder golongan flavanoid yang dapat ditemukan pada tumbuh-tumbuhan dan dikenal mempunyai aktivitas biologi seperti antimikroba, antimalaria, antioksidan, antitumor, dan anti-inflamasi [5]. Struktur dasar Klorokalkon dapat dilihat pada Gambar 1. Selains itu, kalkon juga dapat digunakan sebagai antihepatotoksik. Beberapa kalkon lainnya digunakan sebagai inhibitor tirosin dan juga dilaporkan memiliki aktivitas hipoglikemik [6]. Senyawa kalkon terdiri dari dua cincin aromatik yang dihubungkan oleh suatu keton $\alpha, \beta$ tak jenuh. Senyawa kalkon sangat banyak terdapat di alam terutama pada tumbuhtumbuhan dan merupakan prekursor senyawa flavanoid dan pirazolina [7]. Klorokalkon merupakan salah satu derivat dari kalkon yang dikethaui memiliki aktivitas serta potensi yang baik sebagai antioksidan. Karena sulitnya melakukan isolasi terhadap senyawa kalkon, serta besarnya biaya serta waktu dalam proses sintesis kalkon, maka 
pendekatan secara studi in silico merupakan langkah awal yang efektif dalam pengembangannya menjadi senyawa obat.

\section{METODE PENELITIAN}

Enzim Sirtuin1 diunduh dari situs protein Data Bank (http://www.rcsb.org/pdb/home/home.do) dengan kode pdb (PDB ID:4I5I) diprotononasi dan beberapa senyawa turunan klorokalkon (kerangka dasar seperti yang terlihat pada gambar 1 dan gugus yang dimodifikasi seperti terangkum dalam tabel 1 dioptimasi dengan menggunakan aplikasi Hyperchem yang kemudian disimpan hasilnya dalam bentuk *.mol. Docking senyawa turunan klorokalkon terhadap enzim Sirtuin1 dilakukan menggunakan aplikasi $M O E$ Chemical Computing Group untuk memprediksi jenis ikatan yang terbentuk dan nilai energi ikatan.

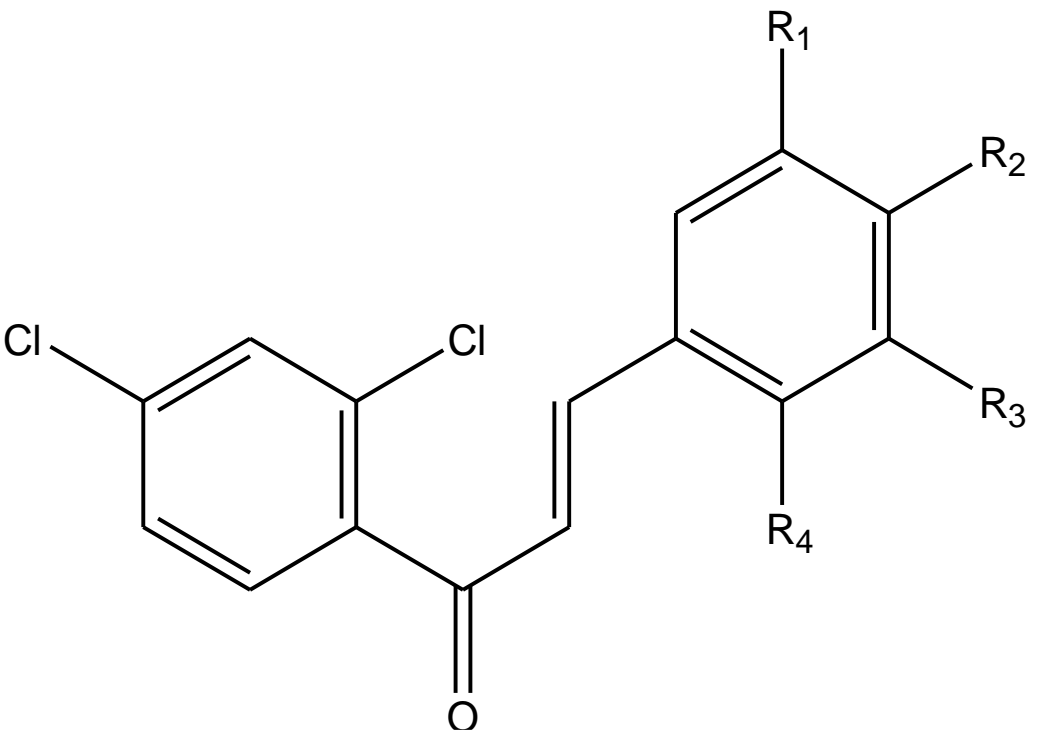

Gambar 1. Struktur dasar klorokalkon yang dioptimasi. Gugus R1, R2, R3, dan R4 dapat dilihat pada Tabel 1.

Tabel 1. Gugus substituen R1, R2, R3, dan R4 yang dimodifikasi dari struktur dasar kalkon pada Gambar 1

\begin{tabular}{lccccc}
\hline No & Kode Senyawa & $\mathrm{R} 1$ & $\mathrm{R} 2$ & $\mathrm{R} 3$ & $\mathrm{R} 4$ \\
\hline 1 & Kalkon 1 & $\mathrm{OCH}_{3}$ & $\mathrm{OH}$ & $\mathrm{H}$ & $\mathrm{H}$ \\
2 & Kalkon 2 & $\mathrm{OCH}_{3}$ & $\mathrm{OCH}_{3}$ & $\mathrm{H}$ & $\mathrm{H}$ \\
3 & Kalkon 3 & $\mathrm{H}$ & $\mathrm{OCH} 3$ & $\mathrm{H}$ & $\mathrm{H}$ \\
4 & Kalkon 4 & $\mathrm{H}$ & $\mathrm{H}$ & $\mathrm{H}$ & $\mathrm{OH}$ \\
5 & Kalkon 5 & $\mathrm{H}$ & $\mathrm{H}$ & $\mathrm{OH}$ & $\mathrm{H}$ \\
6 & Kalkon 6 & $\mathrm{H}$ & $\mathrm{OH}$ & $\mathrm{H}$ & $\mathrm{H}$ \\
7 & Kalkon 7 & $\mathrm{H}$ & $\mathrm{H}$ & $\mathrm{NO}_{2}$ & $\mathrm{H}$ \\
8 & Kalkon 8 & $\mathrm{H}$ & $\mathrm{NO}_{2}$ & $\mathrm{H}$ & $\mathrm{H}$ \\
9 & Kalkon 9 & $\mathrm{H}$ & $\mathrm{Cl}$ & $\mathrm{H}$ & $\mathrm{H}$ \\
10 & Kalkon 10 & $\mathrm{OCH}_{3}$ & $\mathrm{OCH}_{3}$ & $\mathrm{OCH}_{3}$ & $\mathrm{H}$ \\
\hline
\end{tabular}


Tabel 2. Interaksi Senyawa Turunan Kloroalkon dengan Enzim Sirtuin1 (4I5I).

\begin{tabular}{cccc}
\hline Senyawa & S (kcal/mol) & Rsmd & Interaksi \\
\hline Kalkon 1 & -6.95 & 1.42 & Arg274 \\
Kalkon 2 & -7.05 & 1.55 & Ser442 \\
Kalkon 3 & -7.42 & 0.97 & Asn465 \\
& & & Arg466 \\
Kalkon 4 & -6.25 & 0.9 & Asp272 \\
& & & Arg274 \\
Kalkon 5 & -6.81 & 1.42 & Ser442 \\
& & & Arg466 \\
Kalkon 6 & -6.66 & 1.56 & Asp272 \\
& & & Arg274 \\
Kalkon 7 & -7.1 & 1.23 & Ser442 \\
& & & Arg274 \\
& & & Ser 442 \\
Kalkon 8 & -7.21 & 1.42 & Arg466 \\
& & & Ala262 \\
& & & Gly261 \\
Kalkon 9 & -7.06 & 1.13 & Arg274 \\
& & & Asn465 \\
& & & Arg466 \\
Kalkon 10 & -7.91 & & Arg274 \\
& & & Gly261 \\
& & & Ser441 \\
\hline
\end{tabular}

\section{HASIL DAN PEMBAHASAN}

Setelah dilakukan optimasi terhadap kesepuluh senyawa turunan klorokalkon lalu dilakukan docking kesepuluh senyawa turunan klorokalkon terhadap Enzim Sirtuin1 dengan menggunakan aplikasi MOE Chemical Computing Group. Hasil dari docking yang dilakukan dapat dilihat pada tabel 2.

Beberapa senyawa turunan klorokalkon dilakukan docking terhadapa protein target SIRT1. (SIRT1) adalah NAD+-dependent histone deacetylase. Sirtuin mengatur proses transkripsi, stabilitas genom, longevity, dan metabolisme. SIRT1 mengatur proses transkripsi melalui deasetilasi faktor transkripsi seperti PPAR $\gamma$ NFkB dan supressor tumor proein p53. Meningkatnya enzim Sirtuin (SIRT1) akan menurunkan kestabilan p53, gen penanggungjawab terhadap regulasi negatif siklus sel. Protein yang digunakan diperoleh dari Protein Data Bank. Sebelum dilakukan docking, terlebih dahulu solvent pada protein tersebut dihilangkan agar tidak mempengaruhi interaksi antara senyawa uji dengan protein target.

Hasil Docking menunjukkan bahwa senyawa turunan klorokalkon dengan substituen hidroksi, metoksi, dan nitro memiliki interaksi dengan situs aktif dari enzim Sirtuin1 dengan nilai rmsd_refine $<2$ (Tabel 2). Senyawa Kalkon 1, Kalkon 4, dan kalkon 6 berinteraksi dengan asam amino Arg274 membentuk ikatan hidrogen dan membentuk ikatan arenecation dengan dengan asam amino Ser442 dengan energi ikatan berturutturut $-6.95,-6.25$, dan $-6.66 \mathrm{kcal} / \mathrm{mol}$, Kalkon 2 membentuk ikatan hidrogen 
dengan asam amino Ser441dengan energi ikatan sebesar $-7.05 \mathrm{kcal} / \mathrm{mol}$. Kalkon 3 dan kalkon 9 membentuk ikatan hidrogen dengan asam amino Asn 465 dan ikatan arene-H dengan asam amino Arg 466 dan asam amino Asp 272 dengan energi ikatan sebesar -7.42 dan $-7.06 \mathrm{kcal} / \mathrm{mol}$. Kalkon 5 berinteraksi dengan asam amino Arg466 dan Asp272 membentuk ikatan Arene-H dengan energi ikatan $6.81 \mathrm{kcal} / \mathrm{mol}$. Kalkon 7 membentuk interaksi berupa ikatan hidrogen dengan asam amino Arg274, Ser442, Arg466 dengan energi ikatan $-7.1 \mathrm{kcal} / \mathrm{mol}$. Kalkon 8 membentuk ikatan hidrogen dengan asam amino Ala262 dan Gly261, serta interaksi arene-cation teerhadap asam amino Arg274 dengan energi ikatan sebesar -7.21 kcal/mol. Kalkon 10 membentuk katan hidrogen dengan asam amino Gly261 dan Ser441, serta interaksi arene-cation terhadap Arg274 dengan energi ikatan $-7.91 \mathrm{kcal} / \mathrm{mol}$. Interaksi arene-cation merupakan interaksi yang terjadi antara cincin aromatik dengan suatu kation, interaksi ini terjadi karena adanya perbedaan muatan, cincin aromatik yang kaya dengan elektron bermuatan negatif akan berinteraksi dengan kation yang ada pada asam amino [8]. Interaksi hidrogen adalah ikatan yang terjadi antara hidrogen dengan atom $\mathrm{O}$, $\mathrm{N}$, atau $\mathrm{F}$ [9]. Normalnya, atom hidrogen membentuk ikatan kovalen dengan atom lain, namun atom hidrogen yang terikat secara kovalen dengan atom donor tersebut juga dapat berinteraksi membentuk ikatan hidrogen dengan atom akseptor. Adanya interaksi-interaksi tersebut menunjukkan bahwa senyawa kalkon yang telah dibuat dapat berikatan dan membentuk kompleks dengan protein target. Berdasarkan penelitian yang telah dilakukan sebelumnya, simulasi docking beberapa senyawa kalkon terbukti membentuk interaksi Arene-cation pada bagian cincin aromatik dari senyawa kalkon, serta ikatan hidrogen dengan beberapa asam amino, khususnya asam amino arginine [10, 11]. Selain itu, kesepuluh senyawa memiliki nilai energi ikatan yang relatif kecil, semakin kecil nilai energi ikatan yang diperoleh menunjukkan bahwa kompleks senyawa yang terbentuk semakin stabil. Nilai negatif menunjukkan bahwa reaksi yang terjadi terbentuk secara spontan serta meningkatkan afinitas senyawa.

\section{KESIMPULAN}

Senyawa turunan klorokalkon berbasis 2,4-dikloro asetofenon memiliki nilai rsmd_refine $<2$ serta memiliki interaksi hidrogen dan arene-cation terhadap protein enzim Sirtuin1.

\section{DAFTAR PUSTAKA}

[1] Hardjono, S.J.J.I.K.I., Prediksi Sifat Farmakokinetik, Toksisitas dan Aktivitas Sitotoksik Turunan $\mathrm{N}$ Benzoil-N'-(4-fluorofenil) tiourea sebagai Calon Obat Antikanker melalui Pemodelan Molekul. 2017. 14(2): p. 246-255.

[2] Sukandar, E.Y.J.B.D.F.F.I., Tren dan paradigma dunia farmasi. 2002.

[3] Pranowo, H.D.J.t., Peran kimia komputasi dalam desain molekul obat. 2009.

[4] Pranowo, H.D. and A.J.L.A. Hetadi, Bandung, Pengantar Kimia Komputasi. 2011.

[5] Prasad, Y.R., A.L. Rao, and R.J.J.o.C. Rambabu, Synthesis and antimicrobial activity of some chalcone derivatives. 2008. 5(3): p. 461-466.

[6] Patil, C.B., et al., Chalcone: A versatile molecule. 2009. 1(3): p. 11.

[7] Ahmed, M.R., et al., Synthesis and cytotoxic, anti oxidant activities of new chalcone derivatives. 2011. 4(2): p. 289-294.

[8] Meyer, E.A., R.K. Castellano, and F.J.A.C.I.E. Diederich, Interactions with aromatic rings in chemical and biological recognition. 2003. 42(11): p. 1210-1250.

[9] Bruce, P., Organic Chemistry 4th Edition. 2004: p. 959- 994. 
[10] Wulandari, L.I., A. Rahmadani, and R. Rusli, Mekanisme Antibakteri Senyawa Turunan Kalkon 4-asetil piridin. 2018. 3(2): p. 234-241.
[11]Fathullah, A., Prabowo, W., \& Rusli, R. (2018). Interaction of Several Calcon Compounds of Paracetamol Based Toward the Role of Enzyme Protein in Antibacterial Mechanism. Jurnal Kartika Kimia, 1(1), 17-20. https://doi.org/10.26874/jkk.v1i1.10. 